\title{
Kajian Kepekaan Aspal terhadap Temperatur pada Aspal dengan Pemanfaatan Subtitusi Getah Karet Alam
}

\author{
BARKAH WAHYU WIDIANTO, MOCHAMMAD ISA FAISAL
}

\author{
Program Studi Teknik Sipil, Institut Teknologi Nasional Bandung, Indonesia \\ Email: barkah@itenas.ac.id
}

\begin{abstract}
ABSTRAK
Aspal merupakan material pengikat perkerasan lentur yang sangat peka terhadap temperatur. Salah satu cara mengurangi sifat kepekaan tersebut adalah melakukan modifikasi aspal dengan subtitusi getah karet alam sebagai pemanfaatan sumber daya alam. Hal ini didukung dengan peningkatan penghasilan rata-rata karet alam di Indonesia tahun 2015-2020 adalah 1,5\%; dimana penghasilan karet terbesar $28,77 \%$ di Provinsi Sumsel. Penelitian ini bermaksud menganalisis tingkat kepekaan aspal terhadap temperatur dengan nilai indeks penetrasi (IP) aspal dengan nilai penetrasi 60/70 disubtitusi pada persentase tanpa getah dari karet alam; subsitusi 2,5\%; subsitusi 5\%; dan subsitusi 7,5\%. Hasil penelitian menghasilkan bahwa nilai IP semakin meningkat dengan ditambahnya Persentase karet alam; yaitu -0,347 untuk 0\%; -0,179 untuk 2,5\%; 0,419 untuk 5\%; dan 0,557 untuk 7,5\%. Hal ini menunjukkan bahwa dengan bertambahnya persentase karet sehingga aspal bertambah keras dan kurang peka terhadap temperatur karena kandungan getah karet alam yang non bitumen. Hal ini dapat diindikasi bahwa dengan bertambahnya Persentase karet maka aspal semakin tahan terhadap deformasi tetapi rentan terhadap retak.
\end{abstract}

Kata kunci: indeks penetrasi, getah karet alam, aspal

\begin{abstract}
Asphalt is a flexible pavement binder which is very sensitive to temperature. One way to reduce this sensitivity is to modify asphalt by substituting natural rubber latex for the use of natural resources. This is supported by an increase in natural rubber production in Indonesia by an average of $1.5 \%$ in 2015-2020, where the largest rubber production is $28.77 \%$ in South Sumatra Province. This study aims to assess the sensitivity level of bitumen to temperature with the penetration index (IP) value of 60/70 pen asphalt substituted with natural rubber latex levels of without subtitution, 2,5\% subtitution, 5\% subtitution, and 7,5\% subtitution. The test results showed that the IP value increased with the addition of natural rubber content, namely -0.347 for $0 \%,-0.179$ for $2.5 \%, 0.419$ for $5 \%$, and 0.557 for $7.5 \%$. This shows that with increasing rubber content, the asphalt is getting harder and not sensitive to temperature because of the non-bituminous natural rubber latex. It can be indicated that asphalt is increasingly resistant to deformation but susceptible to cracking.
\end{abstract}

Keywords: penetration index, natural rubber latex, asphalt 


\section{PENDAHULUAN}

Aspal merupakan material pengikat pada perkerasan lentur yang sangat peka terhadap temperatur. Salah satu cara mengurangi sifat kepekaan tersebut yaitu dengan melakukan modifikasi aspal. Modifikasi aspal dapat dilakukan dengan menambah atau mensubtitusi bahan selain aspal, salah satunya adalah dengan subtitusi karet alam sebagai pemanfaatan sumber daya alam. Hal ini didukung dengan peningkatan penghasilan karet alam di Indonesia tahun 2015-2020 adalah 1,5\%; dimana penghasilan karet terbesar 28,77\% di Provinsi Sumatera Selatan [1]. Getah yang mengandung karet alam biasa dipakai adalah getah dalam bentuk karet padat. Dengan bertambahnya kadar lateks pada aspal maka penetrasi mengalami penurunan [2]. Presentase kadar lateks yang digunakan adalah 5\%, 10\%, dan 15\%. Penurunan nilai penetrasi diindikasi aspal tersebut semakin keras. Dengan penambahan persentase lateks, maka aspal tersebut memiliki kepekaan terhadap temperatur yang semakin peka [1]. Persentase lateks adalah 3\%, 5\%, dan $7 \%$.

Hasil pengujian menunjukan bahwa pada KAO (Kadar Aspal Optimum) 6,25\% dan penambahan persentase karet sebesar 3,0\% menghasilkan VIM sebesar 3,2\% dari 5,6\% (42,86\%); VMA sebesar 15,8\% dari 17,7\% (-10,73\%); VFA sebesar 79,5\% dari 69,5\% (+14,80\%); stabilitas sebesar $1.150 \mathrm{~kg}$ dari $1.200 \mathrm{~kg}(-4,17 \%)$; flow sebesar 4,5 mm dari 4,25 $\mathrm{mm}(+3,45 \%)$; serta MQ sebesar $258 \mathrm{~kg} / \mathrm{mm}$ dari $280 \mathrm{~kg} / \mathrm{mm}(-7,86 \%)$ [3]. Berdasarkan hasil tersebut, dengan ditambahnya karet maka spesifikasi Marshall dapat dipenuhi. Nilai Indeks Penetrasi (IP) di antara - 1 sampai +1 yaitu nilai IP yang dimiliki aspal sebagai material pada perkerasan jalan [9]. Nilai IP ini berdasarkan hubungan pengujian Titik lembek dan Penetrasi. Pada penelitian ini bertujuan untuk mengkaji tingkat kepekaan aspal terhadap temperatur, serta menganalisis nilai Indeks Penetrasi (IP) aspal dengan penetrasi 60/70 yang disubtitusi dengan persentase getah yang mengandung karet alam tanpa karet alam; subsitusi 2,5\%; subsitusi 5\%; dan subsitusi 7,5\%.

\section{TINJAUAN PUSTAKA}

\subsection{Aspal}

Aspal adalah material perekat yang dihasilkan oleh alam ataupun produksi minyak bumi, berbentuk semipadat atau padat, berwarna gelap atau hitam pekat, berwarna hitam pekat atau gelap [9]. Bitumen dapat berupa pitch, tar, atau aspal. Bitumen seringkali disebut dengan aspal, dan hanya aspal digunakan dalam material campuran pada perkerasan. Residu dari pengilangan pada minyak bumi dapat menghasilkan aspal. Aspal juga dapat dihasilkan dari alam. Aspal memiliki sifat melembek apablia dipanaskan dan kembali mengeras apabila pada temperatur rendah atau disebut dengan termoplastis. Karakteristik ini biasa dilakukan pada konstruksi jalan. Besarnya persentase aspal dalam campuran beraspal berdasarkan berat campuran adalah berkisar $4-10 \%$, atau berdasarkan volume campuran adalah $4-10 \%$.

\subsection{Pengujian Aspal}

Aspal memiliki persyaratan/karakteristik untuk digunakan sebagai material konstruksi yang bersumber pada [4], antara lain:

1. Pengujian Penetrasi bersumber pada SNI 06-2456-1991

Pengujian penetrasi bertujuan untuk mengidentifikasi tingkat kekerasan material aspal. Penetrasi adalah besarnya kedalaman jarum standar dengan diamter $1 \mathrm{~mm}$, dibebani 100 gram, dalam waktu 5 detik, dan temperatur $25^{\circ} \mathrm{C}$. Stuan dinyatakan 0,1 mm.

2. Pengujian Titik lembek bersumber pada SNI 2434:2011

Pengujian Titik lembek dilakukan untuk mengidentifikasi temperatur dimana bola baja yang berada diatas aspal pada cincin berukuran tertentu, terus turun dengan kecepatan pemanasan tertentu, sampai aspal menyentuh plat dasar pada tinggi $25,4 \mathrm{~mm}$. 


\subsection{Temperatur Pencampuran dan Pemadatan}

Pengaruh viskositas aspal sangat penting karena termperatur yang dihasilkan akan digunakan pada temperatur Hot Mixed Asphalt baik saat pencampuran maupun saat pemadatan [10]. Partikel material agregat Hot Mixed Asphalt akan berpengaruh jika adanya kenaikan temperatur saat pemadatan. Pada suhu lebih besar dari $135^{\circ} \mathrm{C}$ akan terjadi kerapatan saat pemadatan. Pada suhu yang lebih rendah ketika pemadatan, kerapatan semakin menurun dengan cepat.

Aspal merupakan material yang bersifat termoplastis dan memiliki kepekaan terhadap temperatur. Aspal akan cair atau lunak jika bertambahnya temperatur dan akan keras atau kental apabila berkurangnya temperatur. Aspal memiliki komposisi kimiawi sehingga aspal memiliki kepekaan temperatur yang berbeda, walaupun memiliki nilai viskositas dan penetrasi pada temperatur yang sama. Informasi rentang temperatur yang digunakan dalam pelaksanaan pekerjaan jalan diperoleh dari pengujian sidat kepekaan aspal terhadap temperatur yang dilakukan.

\subsection{Kepekaan Aspal Terhadap Temperatur}

Sifat termoplastik dimiliki oleh material aspal, yaitu aspal dapat berubah bentuk berdasarkan temperatur, aspal menjadi lunak apabila dipanaskan pada temperatur tinggi dan menjadi keras apabila didinginkan pada temperatur rendah [11]. Indeks Penetrasi (IP) menunjukkan nilai kepekaan aspal terhadap temperatur tersebut. Penentuan Indeks Penetrasi (IP) dapat ditunjukan pada Persamaan 1 hingga Persamaan 3 di bawah ini. Sensitifitas aspal dapat dilihat pada nilai A yang bertujuan sama dengan nilai IP dimana memiliki fungsi dari nilai IP.

Pada konsepnya material aspal bersifat termoplastis, yaitu material yang dapat berubah melunak jika dipanaskan dan berubah keras jika didinginkan. Nilai sensitivitas aspal terhadap temperatur menunjukkan nilai Penetration Index (PI). Terdapat persamaan untuk menganalisis nilai Penetration Index (PI), seperti pada Persamaan 1 hingga Persamaan 3. Nilai slope A menunjukkan fungsi dari nilai PI.

Nilai Indeks Penetrasi (IP) [7] aspal dapat ditentukan dari Persamaan 1 berikut:

$$
P I=\frac{20(1-25 A)}{1+50 A}
$$

Berdasarkan nilai penetrasi di dua temperatur, dengan tujuan yang sama, Indeks Penetrasi (IP) memiliki fungsi dari nilai A seperti pada Persamaan $\mathbf{2}$ berikut:

$$
A=\frac{\text { log.pen } \cdot T_{1}-\log \cdot \text { pen } \cdot T_{2}}{T_{1}-T_{2}}
$$

Pada softening point atau titik lembek sebagian besar aspal memiliki nilai penetrasi adalah 800 mm sehingga pada Persamaan $\mathbf{3}$ berubah:

$$
A=\frac{\log \cdot p e n \cdot T_{1}-\log \cdot 800}{T_{1}-S P}
$$

Nilai IP yang digunakan dalam material pada konstruksi jalan adalah antara -1 sampai +1 .

\subsection{Getah Karet}

Getah yang mengandung karet alam adalah polimer dari alam bahan modifikasi aspal yang dapat dimanfaatkan [8]. Sifat lekat dan plastis yang lebih baik dari bahan polimer sintetis 
mengakibatkan akret alam dapat digunakan sebagai aditif dan diprediksi akan lebih baik. Karet alam mempunyai sifat elastisitas baik, daya regang tinggi, daya kenyal dan resilien yang baik. Produk karet alam sebagai aspal modifikasi ada 2 (dua) jenis, yaitu lateks dan karet padat. Jika dibandingkan dengan karet padat, lateks mempunyai kelebihan mudah ketika dicampurkan pada Hot Mixed Asphalt. Apabila dilihat dari jenis dan bentuk karet lainnya, lateks juga dipilih menjadi bahan modifikasi pada campuran aspal panas yang lebih efisien.

Kelemahan yang dimiliki oleh getah karet alam, yaitu lemah terhadap reaksi ozon dan oksidasi dikarenakan pada struktur molekul karet alam memiliki banyaknya ikatan rangkap [6]. Karet alam juga memiliki kelebihan seperti: memiliki sifat fisik kepegasan tinggi, elastisitas baik dan kuat, serta mempunyai daya pantul yang baik.

Getah karet alam digunakan untuk peningkatan mutu campuran beraspal pada perkerasan jalan dan mutu material aspalnya [12]. Getah karet alam (Gambar 1) yang dimodifikasi dengan aspal yaitu campuran aspal yang mengandung getak karet alam yang bertujuan dalam peningkatan kelekatan aspal pada agregat, peningkatan ketahan terhadap potensi retak, serta pengurangan potensi retak di perkerasan. Pencampuran getah karet alam pada aspal di perkerasan jalan bermanfaat dalam peningkatakan produksi getah karet alam di Indonesia. Pemanfaatan ini juga akan berpotensi pada peningkatan kualitas perkerasan jalan, peningkatan umur layan perkerasan, serta pengurangan biaya saat pemeliharaan.

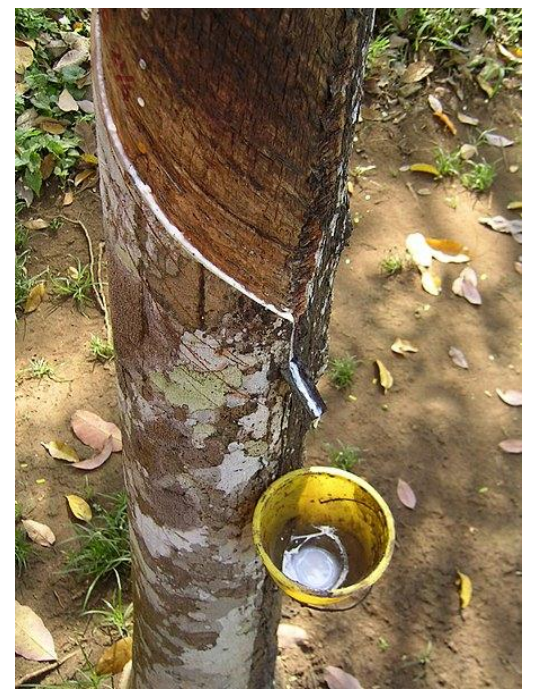

\section{Gambar 1. Getah yang mengandung karet alam di Pangkalan Balai, Sumsel}

\subsection{Pengujian Hipotesis}

Statistik hipotesis merupakan statistik pada fungsi populasi [8]. Statistik merupakan suatu ukuran yang digunakan pada sampel, yaitu $r$ merupakan koefisien korelasi, $s^{2}$ merupakan varians, $x$ merupakan nilai rata-rata, dan $s$ merupakan nilai simpangan baku. Sedangkan parameter merupakan ukuran-ukuran yang digunakan di populasi, yaitu $\mu$ merupakan ratarata, $\sigma$ merupakan simpangan baku, $\sigma^{2}$ merupakan varians, dan $\rho$ merupakan koefisien korelasi. Pada definisi lainya, hipotesis merupakan taksiran pada fungsi populasi, dengan sampel. Penelitian deskripsi merupakan penelitian yang berdasarkan sampling total, sensus, atau data populasi.

a. Pengujian Satu sampel atau Hipotesis Deskriptif

Pengujian satu sampel atau hipotesis deskriptif yaitu eksperimen generalisasi dari hasil penelitian dan berdasarkan dari satu sampel [8]. Hasil kesimpulan merupakan hipotesis 
yang diuji dengan digeneralisasikan atau tidak. Hipotesis dapat digeneralisasi jika $H_{0}$ diterima. Hipotesis penelitian bukan perbandingan atau gubungan antara beberapa variable jika penelitian bersifat mandiri.

b. Uji Chi Kuadrat $\left(x^{2}\right)$

Chi Kuadrat $\left(x^{2}\right)$ satu sampel merupakan cara statistik untuk menguji hipotesis, jika terdapat populasi yang terdiri dari beberapa kelas dimana data dalam bentuk nominal [8]. Nilai Chi Kuadrat harus dicek perbandingannya dengan Chi Kuadrat tabel dengan $d_{k}$ dan taraf kesalahan tertentu jika keputusan hipotesis yang dihasilkan akan ditolak atau diterima. Berdasarkan hal tersebut berlaku nila Chi Kuadrat tabel lebih tinggi dari Chi Kuadrat hitung, pada kesimpulannya $H_{0}$ diterima. $H_{0}$ tidak diterima jika Chi Kuadrat hitung lebih tinggi atau sama dengan Chi Kuadrat tabel.

\section{METODOLOGI}

Penelitian dilakukan dari identifikasi masalah serta penentuan topik yaitu sifat dasar aspal yang peka terhadap temperatur yang mengakibatkan indikasi kerusakan deformasi permanen. Kemudian diupayakan pada modifikasi dengan pemanfaatan getah karet alam yang bersifat elastomer dan berkelanjutan. Penelitian ini didukung dari studi yang sudah dilakukan dan sumber-sumber terkait. Pengumpulan data sekunder dilakukan berdasarkan studi terdahulu. Proses pertama adalah pencampuran getah karet alam dengan aspal yang dilakukan di laboratorium Pusjatan [12]. Kecepatan, waktu, dan temperatur pencampuran [5]. Getah karet alam dan aspal dicampur pada temperatur $150^{\circ} \mathrm{C}$, selama 60 menit, dan kecepatan $6.000 \mathrm{rpm}$. Kemudian dilakukan pengujian titik lembek dan penetrasi aspal yang disubtitusi getah karet alam dengan subsitusi 2,5\%; 5\%, dan 7,5\%. Eksperimen berdasarkan Spesifikasi Umum Bina Marga 2018. Data yang dihasilkan kemudian dianalisis berdasarkan kajian kepekaan aspal terhadap temperatur dari nilai indeks penetrasi pada aspal yang telah disubtitusi oleh getah karet alam. Pada saat kesimpulan, diperoleh kajian kepekaan aspal terhadap temperatur dan berdasarkan nilai tersebut dapat diketahui perubahan kepekaan aspal terhadap temperatur dengan penambahan persentase getah karet alam.

\section{HASIL DAN PEMBAHASAN}

\subsection{Hasil Pengujian Laboratorium}

Hasil pengujian laboratorium [12] didapat rekapitulasi hasil pengujian sifat aspal yang disubtitusi getah karet alam dengan subsitusi $0 \%$; subsitusi $2,5 \%$; $5 \%$; dan subsitusi $7,5 \%$ dapat dilihat pada Tabel 1 di bawah ini.

Tabel 1. Hasil Pengujian Penetrasi dan Titik Lembek

\begin{tabular}{|c|c|c|c|c|c|c|c|c|c|c|c|}
\hline \multirow[t]{2}{*}{ No } & \multirow[t]{2}{*}{ Pengujian } & \multirow[t]{2}{*}{ Satuan } & \multicolumn{2}{|c|}{$\begin{array}{c}0 \% \\
\text { Persentase } \\
\text { Getah Karet }\end{array}$} & \multicolumn{2}{|c|}{$\begin{array}{c}\mathbf{2 , 5} \% \\
\text { Persentase } \\
\text { Getah Karet }\end{array}$} & \multicolumn{2}{|c|}{$\begin{array}{c}\mathbf{5 \%} \\
\text { Persentase } \\
\text { Getah Karet }\end{array}$} & \multicolumn{2}{|c|}{$\begin{array}{c}\mathbf{7 , 5} \% \\
\text { Persentase } \\
\text { Getah Karet }\end{array}$} & \multirow[t]{2}{*}{ Spek } \\
\hline & & & Hasil & Spek & Hasil & Spek & Hasil & Spek & Hasil & Spek & \\
\hline 1 & Penetrasi & $\mathrm{dmm}$ & 67,3 & - & 59,3 & - & 57,1 & - & 55,3 & - & dilaporkan \\
\hline 2 & Titik Lembek & ${ }^{\circ} \mathrm{C}$ & 50,5 & - & 52,5 & - & 55,5 & - & 56,5 & - & dilaporkan \\
\hline
\end{tabular}

Dari Tabel 1 di atas dapat dijelaskan bahwa perubahan karateristik aspal dengan subtitusi getah karet alam memiliki peningkatan nilai titik lembek dan penurunan nilai penetrasi. 


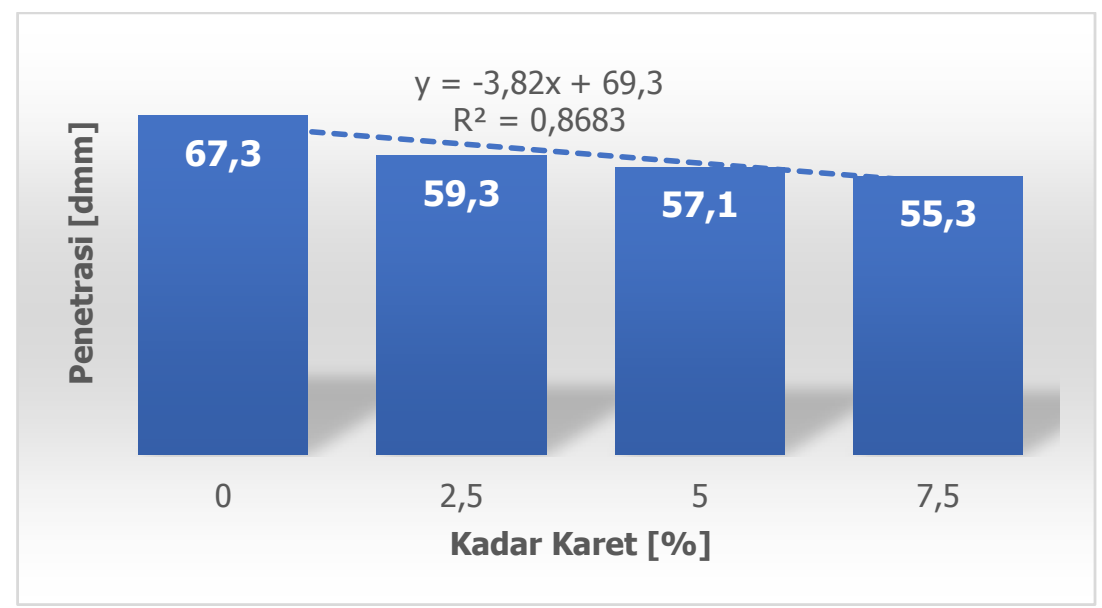

Gambar 2. Perubahan nilai penetrasi aspal

Dari Gambar 2 di atas dapat diketahui bahwa terjadinya penurunan nilai penetrasi dengan penambahan getah karet alam. Penurunan nilai penetrasi dapat diindikasi bahwa sifat fisik aspal akan bertambah keras. Hal ini seiring dengan bertambahnya persentase kadar karet alam. Besarnya nilai penetrasi pada persentase getah karet alam, yaitu pada $0 \%$ adalah 67,3 dmm; pada 2,5\% adalah 59,3 dmm; pada $5 \%$ adalah $57,1 \mathrm{dmm}$; dan pada $7,5 \%$ adalah 55,3 dmm. Presentase penurunan terjadi pada $0 \%$ dan 2,5\% adalah $11,88 \%$; pada $2,5 \%$ dan $5 \%$ adalah $3,85 \%$; dan pada $5 \%$ dan $7,5 \%$ adalah $3,25 \%$.

\section{Tabel 2. Analisis Uji Kruskal Wallis dan Uji Chi Kuadrat pada Uji Penetrasi}

\begin{tabular}{lc}
\hline & Penetrasi \\
\hline Chi-Square & 6,667 \\
\hline df & 3 \\
Asymp. Sig. & 0,083 \\
\hline a. Test of Kruskal Wallis \\
b. Variable of Grouping: \\
Persentase Getah \\
Karet [\%]
\end{tabular}

Dari Tabel 2 dapat dilihat bahwa hasil pengujian Kruskal Wallis untuk penetrasi. Dapat dilihat bahwa hasil Asymp.Sig menghasilkan 0,083 > 0,05; sehingga tidak ada rata-rata perbedaan pada nilai penetrasi antara persentase subsitusi tanpa getah karet alam, subsitusi 2,5\%; subsitusi $5 \%$; dan subsitusi 7,5\% atau $H_{0}$ diterima. Untuk Uji Chi Kuadrat didapat Chi kuadrat hitung menghasilkan 6,667 sedangkan Chi Kuadrat tabel didapat 7,815. Dikarenakan Chi Kuadrat tabel lebih tinggi dibandingkan Chi Kuadrat hitung sehingga $H_{0}$ diterima atau tidak adanya perbedaan karakteristik pada nilai penetrasi antara persentase subsitusi tanpa getah karet alam; subsitusi 2,5\%; subsitusi 5\%; dan subsitusi 7,5\%. 


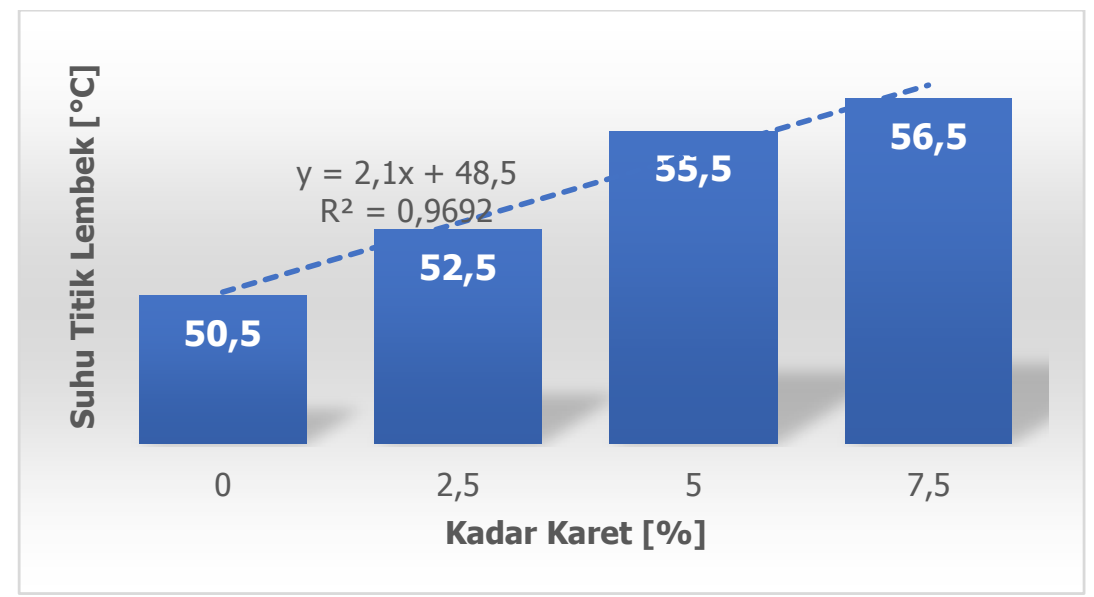

Gambar 3. Perubahan nilai titik lembek aspal

Dari Gambar 3 di atas juga dapat diketahui bahwa terjadinya peningkatan nilai titik lembek dengan penambahan getah karet alam. Peningkatan temperatur titik lembek dapat diindikasi bahwa sifat fisik aspal akan bertambah keras dan memerlukan temperatur yang cukup tinggi dalam mencapai titik lembek. Hal ini seiring dengan bertambahnya persentase kadar karet alam. Besarnya nilai titik lembek pada persentase getah karet alam; yaitu pada $0 \%$ adalah $50,5^{\circ} \mathrm{C}$; pada $2,5 \%$ adalah $52,5^{\circ} \mathrm{C}$; pada $5 \%$ adalah $55,5^{\circ} \mathrm{C}$; dan pada $7,5 \%$ adalah $56,5^{\circ} \mathrm{C}$. Persentase penurunan terjadi pada $0 \%$ dan $2,5 \%$ adalah $3,96 \%$; pada $2,5 \%$ dan $5 \%$ adalah $5,71 \%$ dan pada $5 \%$ dan $7,5 \%$ adalah $1,80 \%$.

Tabel 3. Analisis Uji Kruskal Wallis dan Uji Chi Kuadrat pada Uji Titik Lembek

\begin{tabular}{cc}
\hline \multicolumn{3}{c}{ Penetrasi } \\
\hline Chi-Square $\quad 6,452$ \\
\hline df $\quad 3$ \\
Asymp. Sig. 0,092 \\
\hline a. Test of Kruskal Wallis \\
b. Variable of Grouping: \\
Persentase Getah \\
Karet [\%]
\end{tabular}

Dari Tabel 3 dapat dilihat bahwa hasil pengujian Kruskal Wallis untuk titik lembek. Dapat dilihat bahwa hasil Asymp.Sig memiliki nilai 0,092 > 0,05; sehingga tidak ada rata-rata perbedaan pada nilai titik lembek antara Persentase subsitusi tanpa getah karet alam, subsitusi 2,5\%; subsitusi 5\%; dan subsitusi 7,5\% atau $H_{0}$ diterima. Untuk Uji Chi Kuadrat didapat Chi Kuadrat hitung menghasilkan 6,452 sedangkan Chi Kuadrat tabel didapat 7,815. Karena Chi Kuadrat tabel lebih tinggi dibandingkan Chi Kuadrat hitung maka $H_{0}$ diterima atau tidak adanya perbedaan karakteristik pada nilai titik lembek antara persentase subsitusi tanpa getah karet alam; subsitusi $2,5 \%$; subsitusi $5 \%$; dan subsitusi $7,5 \%$. 


\subsection{Analisis Kepekaan Aspal terhadap Temperatur}

Berdasarkan hasil pengujian karakteristik aspal yaitu penetrasi dan titik lembek, serta Persamaan 1 hingga Persamaan 3 maka didapat nilai Kemiringan (sensitivitas) A dan Indeks Penetrasi (IP). Berikut perhitungan analisis pada persentase karet $0 \%$, maka mendapatkan nilai A dan PI seperti pada Persamaan 4 dan Persamaan 5 di bawah ini:

$$
\begin{aligned}
& A=\frac{\text { log.pen } \cdot 25-\log \cdot \text { pen } .800}{25-50,5}=0,042 \\
& P I=\frac{20(1-25 \cdot 0,042)}{1+50(0,042)}=-0,35
\end{aligned}
$$

Nilai IP -0,35 pada persentase karet $0 \%$ menunjukkan bahwa tingkat kepekaan aspal terhadap temperatur yang tinggi. Nilai ini berdasarkan dari nilai titik lembek yang tinggi. Untuk rekapitulasi perhitungan nalisis pada Persentase karet $0 \%$; 2,5\%; 5\%; dan $7 \%$ maka mendapatkan nilai A dan PI seperti pada Tabel 4 serta Gambar 4 berikut.

Tabel 4. Rekapitulasi Indeks Penetrasi

\begin{tabular}{ccccccc}
\hline $\begin{array}{c}\text { Persentase Karet } \\
{[\%]}\end{array}$ & T1 & Pen T1 & T2 (SP) & Pen T2 & A & IP \\
\hline 0 & 25 & 67,3 & 50,5 & 800 & 0,042 & $-0,35$ \\
\hline 2,5 & 25 & 59,3 & 52,5 & 800 & 0,041 & $-0,18$ \\
\hline 5 & 25 & 57,1 & 55,5 & 800 & 0,038 & 0,42 \\
\hline 7,5 & 25 & 55,3 & 56,5 & 800 & 0,037 & 0,56 \\
\hline
\end{tabular}

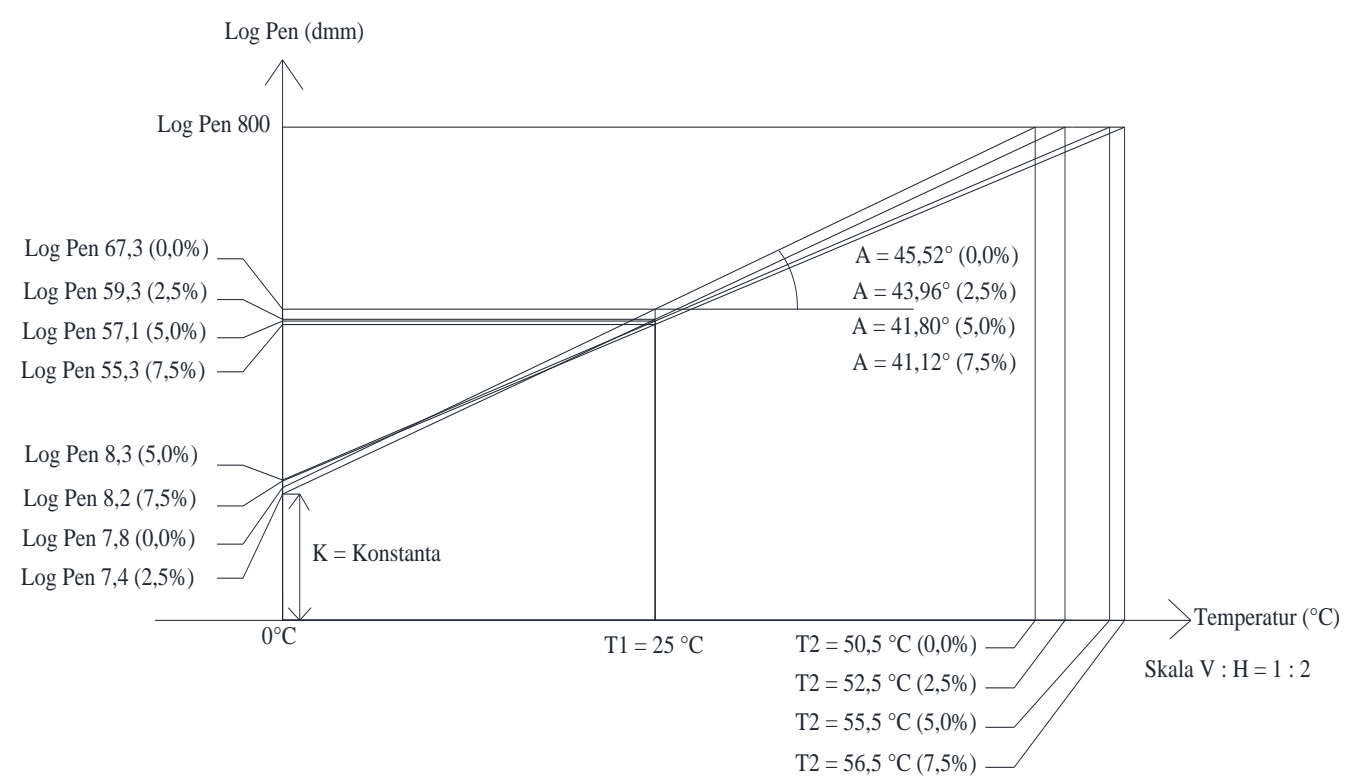

Gambar 4. Grafik hubungan temperatur dan Log Pen aspal

Pada Gambar 4 dan Tabel 4 di atas diketahui bahwa aspal dengan persentase karet alam $0 \%$ memiliki kepekaan terhadap temperatur paling tinggi dibandingkan persentase getah karet yang lain, yaitu dengan nilai A sebesar $45,52^{\circ}$ atau 0,042 dan IP sebesar $-0,35$. Kemudian kedua adalah aspal dengan persentase karet alam 2,5\% yaitu $43,96^{\circ}$ atau 0,041 dan IP sebesar $-0,18$, ketiga adalah aspal dengan persentase karet alam $5,0 \%$ yaitu $41,80^{\circ}$ atau 0,038 dan IP sebesar 0,42; dan keempat adalah aspal dengan persentase karet alam 7,5\% yaitu $41,12^{\circ}$ atau 0,037 dan IP sebesar 0,56. 


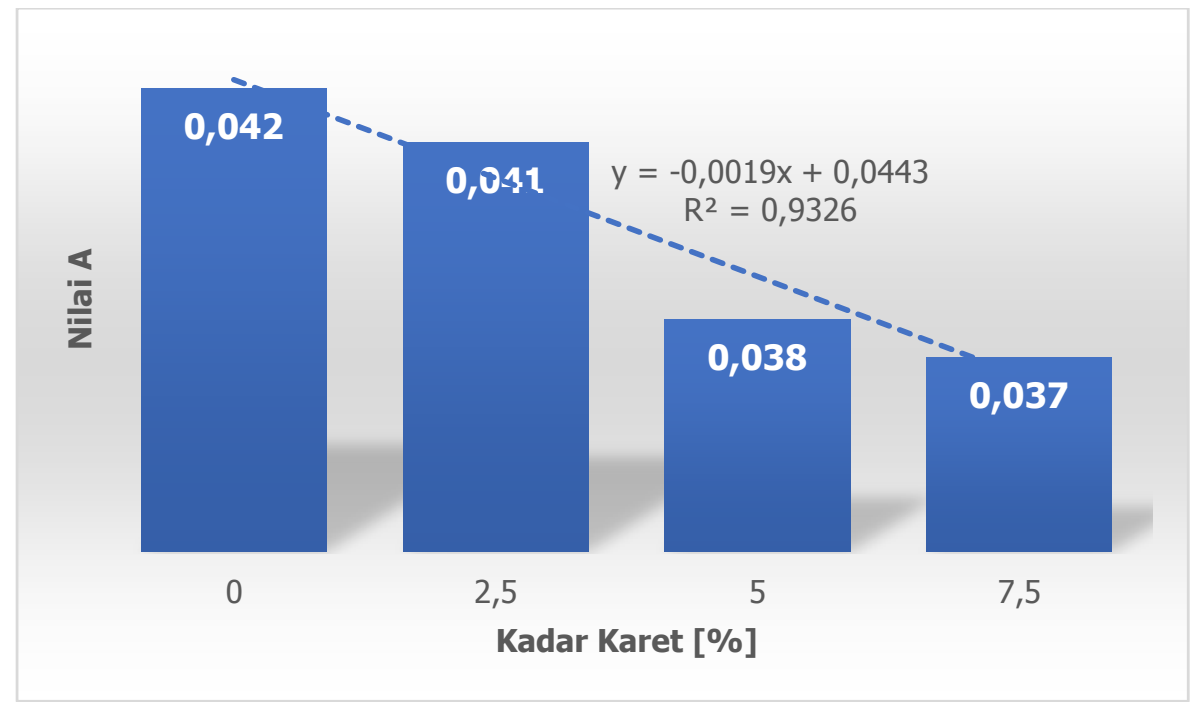

Gambar 5. Perubahan nilai A pada aspal

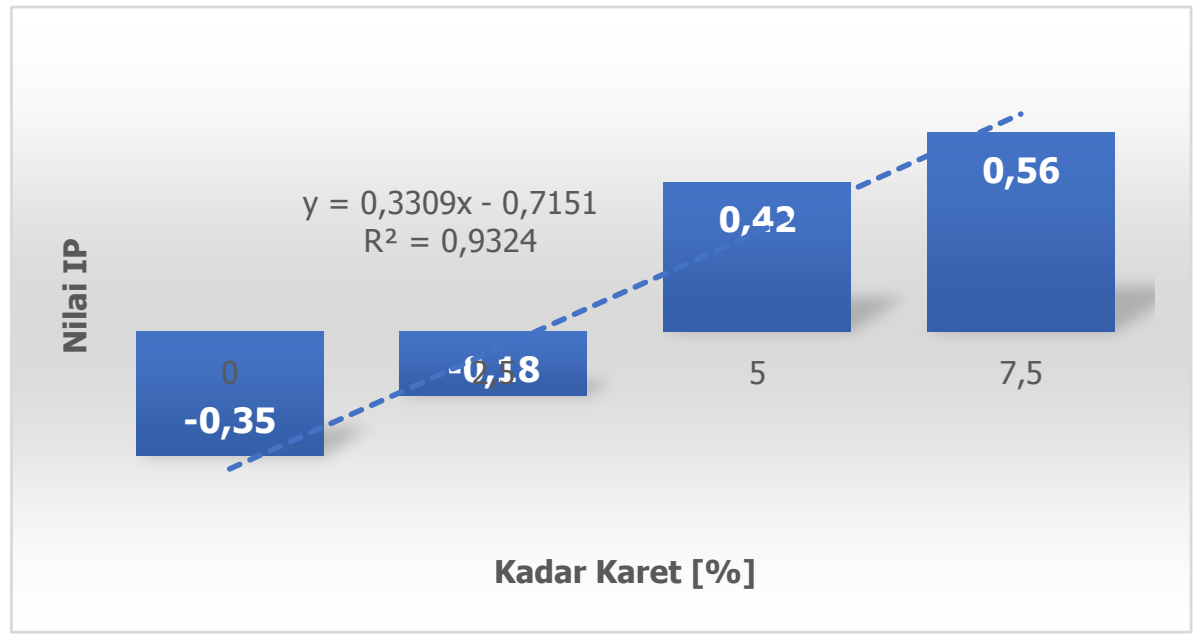

Gambar 6. Perubahan nilai IP pada aspal

Berdasarkan Gambar 5 serta Gambar $\mathbf{6}$ dapat dijelaskan semakin bertambahnya persentase karet, maka terjadi penurunan nilai A dan dan peningkatan nilai Indeks penetrasi (IP). Nilai Indeks Penetrasi ini akan mempengaruhi kemampuan aspal pada setiap persentase subtitusi karet alam terhadap kepekaan temperatur di lapangan, dimana semakin bertambahnya persentase getah karet sehingga aspal akan semakin kurang peka terhadap temperatur (mendekati positif 1). Hal ini juga dapat diindikasikan bahwa semakin aspal tidak peka terhadap temperature, maka aspal akan semakin keras serta lebih tahan saat deformasi permanen dan sebaliknya rentan terhadap retak.

\section{KESIMPULAN}

Dari hasil pembahasan dapat disimpulkan sebagai berikut

1. Pengujian aspal dengan nilai penetrasi $60 / 70$ dengan subtitusi getah yang mengandung karet alam diperoleh bahwa semakin bertambahnya persentase karet, maka nilai penetrasi mengalami penurunan sedangkan nilai titik lembek mengalami peningkatan.

2. Berdasarkan hasil pembahasan uji Kruskall Wallis dan Uji Chi Kuadrat, menunjukan tidak terjadi perbedaan rata-rata antara persentase getah karet dengan hasil pengujian. 
3. Hasil analisis Indeks Penetrasi (IP) menunjukkan bahwa bertambahnya persentase karet alam maka semakin kurang peka aspal terhadap temperatur. Hal ini berdasarkan nilai A yang semakin kecil dan nilai IP yang mendekati nilai 1 .

4. Perubahan sifat fisik aspal yang diperoleh menunjukan aspal akan bertambah keras dan aspal semakin kurang peka terhadap temperatur seiring dengan bertambahnya presentase getah karet alam. Hal ini dikarenakan kandungan non bitumen pada getah karet alam dan sifatnya yang elastis.

5. Penambahan persentase karet alam pada aspal akan meningkatkan ketahanan deformasi permanen tetapi memiliki kerentanan terhadap retak. Dengan peningkatan presentase getah karet alam diindikasi membutuhkan temperatur yang tinggi pada saat pencampuran dan pemadatan.

\section{DAFTAR PUSTAKA}

[1] Ali, D.Y. (2010). Pemanfaatan Lateks Karet Alam Sebagai Bahan Pemodifikasi Aspal Untuk Meningkatkan Mutu Perkerasan Aspal. Tugas Akhir. Bogor: Departemen Teknologi Industri Pertanian - Institut Pertanian Bogor.

[2] Debrina, D. (2005). Studi Penggunan Lateks Pada Aspal Sebagai Campuran Lapisan Permukaan Aspal Porus. Tugas Akhir. Bandung: Jurusan Teknik Sipil - Institut Teknologi Nasional Bandung.

[3] Hawinuti, R. (2020). Karakteristik Campuran Aspal Karet pada Lataston Lapis Aus (HRSWC). Jurnal Gradasi Teknik Sipil, 4(1), pp.

[4] Kementerian Pekerjaan Umum dan Perumahan Rakyat, (2018). Spesifikasi Umum Pekerjaan Jalan dan Jembatan 2018. Jakarta: Direktorat Jenderal Bina Marga.

[5] Kementerian Pekerjaan Umum dan Perumahan Rakyat. (2018). Penerapan Terbatas Aspal Plastik dan Aspal Karet di Jalan Lingkungan Pusjatan. Bandung: Pusat Penelitian dan Pengembangan Jalan dan Jembatan.

[6] Ramadhan, A., Prastanto, H., \& Alfa, A.A. (2005). Pengaruh Waktu Reaksi Depolimerisasi terhadap Viskositas Mooney Karet Mentah pada Proses Pembuatan Karet Alam Cair Sistem Redoks. Yogyakarta: Yayasan Media Utama.

[7] Shell Bitumen (2003). The Shell Bitumen Handbook. UK: Shell Bitumen.

[8] Sugiyono. (2012). Statistika untuk Penelitian. Bandung: Alfabeta.

[9] Sukirman, S. (2016). Beton Aspal Campuran Panas. Bandung: Nova.

[10] Suparyanto. (2008). Pengaruh Penggunaan Aspal Pertamina AC 60/70 dan Aspal Shell AC 60/70 Terhadap Deformasi Permanen Campuran Beton Aspal (Spesifikasi Bina Marga 2007) Dikaitkan Dengan Temperatur Pemadatan Menggunakan Alat Uji Wheel Tracking. Tesis. Yogyakarta: Univeritas Gajah Mada.

[11] Widianto, B.W., (2012). Kajian Life Cycle Cost terhadap Perkerasan Jalan Campuran Lapis Aus (AC-WC) yang menggunakan BNA Blend 75/25. Tesis. Bandung: Institut Teknologi Bandung.

[12] Widianto, B.W. (2020). Perubahan Karakteristik Aspal Pen 60/70 dengan Subtitusi Getah Karet Alam Pangkalan Balai, Sumatera Selatan. RekaRacana: Jurnal Teknik Sipil, 6(3), pp. 